\title{
Powering development: the political economy of electricity generation in the EPRDF's Ethiopia
}

Tom Lavers ${ }^{1}$

Biruk Terrefe ${ }^{2}$

Fana Gebresenbet ${ }^{3}$

${ }^{1}$ Global Development Institute, University of Manchester, UK

${ }^{2}$ University of Oxford, UK

${ }^{3}$ Addis Ababa University, Ethiopia

\section{FutureDAMS}

\section{Working Paper 014}

January 2021

ISBN: 978-1-913093-14-3

Cite this paper as: Lavers, T., Terrefe, B. and Gebresenbet, F. (2021) Powering development: the political economy of electricity generation in the EPRDF's Ethiopia. FutureDAMS Working Paper 0014. Manchester: The University of Manchester.

www. FutureDAMS.org 


\begin{abstract}
This paper examines the political economy of electricity generation planning in Ethiopia during the EPRDF era (1991-2019), highlighting the importance of power relations between politicians and the bureaucracy, the political interests of the ruling party and the dominant ideas shaping politics and the electricity sector. To do this, the research draws on more than 100 key informant interviews with politicians, government officials, consultants and donors involved in the sector. The paper argues that the ruling party's approach to electricity was emblematic of the successes and limitations of its 'developmental state' project pursued over the past 20 years. The increased supply of low-cost electricity is seen as a key input into industrial policy, a means of securing foreign exchange and a mechanism for legitimating the ruling party among the population. Moreover, the narratives used to justify massive investment in electricity generation mirror the party's changing ideological reference points, from Marxism to the developmental state to a recent and tentative turn to liberalisation.

Electricity supply has increased significantly over this period, with further large-scale projects nearing completion. However, the huge developmental ambitions of the political elite have at times undermined the planning process in the sector, leading to an emphasis on megaprojects to meet implausible estimates of future demand and questionable project design.
\end{abstract}

\title{
Keywords
}

Electricity, governance, politics, policy making

\section{JEL Codes}

O13; O21; O55; P41; P48; Q48

\section{Acknowledgements}

FutureDAMS is a consortium of over 30 researchers developing the knowledge base, tools and approach for designing interventions in systems to support resilient and sustainable development in a warming world. This work was supported by the UK Research and Innovation-Economic and Social Research Council [ES/P011373/1] as part of the Global Challenges Research Fund. The paper has benefited from comments on previous versions by Barnaby Dye, David Hulme and Mohammed Basheer, as well as by two anonymous reviewers. 


\section{Contents}

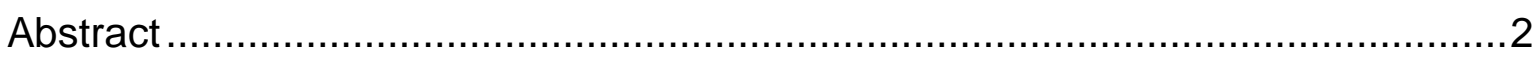

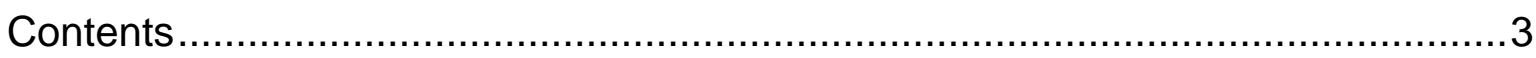

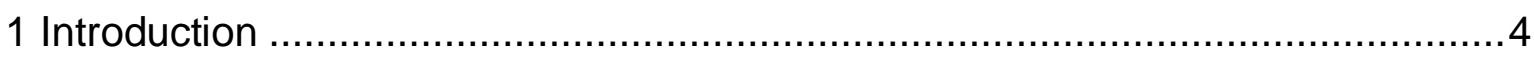

2 Power and electricity within the EPRDF's developmental project .................... 7

3 Political ambitions and technical expertise in the electricity sector ...................11

4 Delivering development: targets, ambition and incentives........................... 13

5 Developmental vision and the perils of excessive ambition? ...........................20

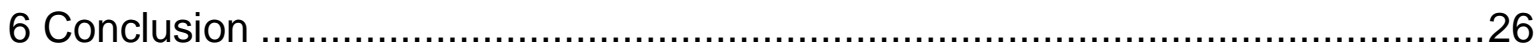

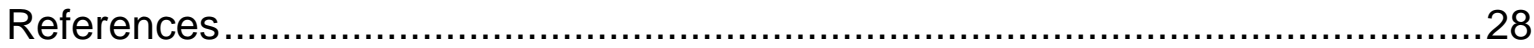

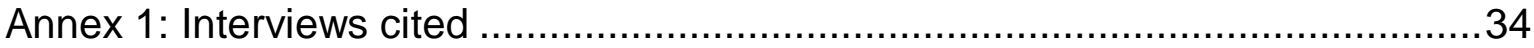




\section{Introduction}

Electricity is widely seen as key to development. Universal access to affordable, reliable and sustainable electricity is included within the 2030 targets for the UN Sustainable

Development Goals, while some consider access to electricity to be a human right (Löfquist, 2019). Moreover, expanding the provision of affordable and reliable electricity is a key input for other economic sectors and a necessity for the structural transformation of the economy. Given the growing acknowledgement of the dangers of climate change, developing countries face a particularly acute challenge of significantly expanding generation capacity through renewable energy sources. This paper takes the case of Ethiopia as a self-styled 'developmental state' where electricity is seen as a key input to the government's plans for industrialisation and structural transformation of the economy. Ethiopia aims to become a major regional electricity exporter in the coming years, while maintaining its commitment to net zero emissions. The central pillar of this strategy is a massive dam building programme, which has made Ethiopia one of the key protagonists in the dam resurgence of the past 15 years (Zarfl et al, 2015; Dye, 2018).

This paper examines the political economy of the electricity sector, focusing on how key actors, their interrelations and their misaligned incentives have shaped decision making. ${ }^{1}$ To date there have been several contributions to the literature that have modelled future demand and the potential of different energy sources to meet this, assessed the impact of electricity shortages on growth, or examined the challenge of integrating renewable energy production into Ethiopia's hydropower-focused energy system (Block \& Strzepek, 2012; Asress et al, 2013; Demissie \& Solomon, 2016; Mondal et al, 2017). However, there are relatively few contributions from a social science, much less a political economy, perspective. Cuesta-Fernández (2016) provides a very useful analysis of electricity in Ethiopia, but with a focus on the challenges of realising the country's targets for exports. In doing so, the chapter does not engage deeply with domestic political economy and, in retrospect, is somewhat optimistic regarding the completion of some of Ethiopia's 'mammoth dams' and even the ability to meet domestic demand. Beyond this, a number of studies have focused on decision making around particular projects, often highlighting how the political economy of Ethiopian development has shaped projects such as the Gilgel Gibe III dam (Hailu Woldegebrael, 2018) and the Adama windfarms (Chiyemura, 2019). Moreover, Verhoeven (2013) focuses on Ethiopia's dam building programme more broadly, highlighting the importance of dams to the government's development and state-building strategy. The paper seeks to build on these earlier contributions by examining the path-dependent processes and key relationships which have shaped strategic decisions regarding the expansion of generation capacity. The paper is the first in a series of FutureDAMS papers that will examine the political economy dynamics shaping dams and the electricity sector in Ethiopia.

Our analytical framework focuses on the interplay of material interests and the ideological commitments of actors, and the power relations between them. Drawing on the framework set out for the broader research programme (Lavers \& Dye, 2019) of which this paper is part,

\footnotetext{
${ }^{1}$ The focus in this paper is on the state-led investment in electricity generation. The recent turn towards private investment is considered in a separate paper.
} 
the analysis highlights relations between two main sets of actors. The first concerns relations within the political elite. We focus on how power is centralised and dispersed, as well as on the nature of elite coherence. A number of recent influential contributions have highlighted the importance of intra-elite cohesion for state-led development (Waldner, 1999; Doner et al, 2005; Khan, 2010). For these authors, a cohesive political elite can be an important factor in limiting the political capture of government policy by powerful social and economic actors; directing scarce resources towards productive investment rather than consumption; enabling a long time horizon in planning processes; and ensuring consistency in decision making, based on a common ideological reference point (Khan, 2010; Lavers, 2018; Gray, 2019). Most of this literature has focused on industrial policy, rather than electricity generation specifically. However, large-scale public investment in infrastructure, including electricity generation to ensure low-cost supplies for industry, has nevertheless been an important feature of state-led development (Amsden, 1992, pp 91-92; Kohli, 1999). Moreover, the high levels of investment required for major expansion of energy infrastructure and the long gestation period for energy generation projects suggest the importance of elite cohesion for decision making in the sector.

Yet one limitation of this literature is the relative inattention paid to a second set of relations - that between the political elite and the bureaucracy. The underlying assumption of many of these contributions appears to be that, once the challenge of cohesion among the political elite is resolved, investment in the bureaucratic capacity required to plan and implement development projects will follow. Yet analysts of East Asian state-led development have highlighted the development of bureaucratic capacity as an essential step, involving a delicate balance of relations between politicians, bureaucrats and societal actors (Evans, 1995; Kohli, 2004). Perhaps most famously, Chalmers Johnson's (1982, p 316) analysis of the Japanese 'developmental state' highlighted the importance of a politically empowered bureaucracy:

the politicians reign and the bureaucrats rule. But it must be understood that the bureaucrats cannot rule effectively if the reigning politicians fail to perform their positive tasks, above all, to create space for bureaucratic initiative unconstrained by political power.

The electricity sector is highly technical and requires high levels of training and expertise. Electricity planning therefore requires not just the long-term planning and coherence that is shaped by relations within the political elite, but also a capable and politically empowered technocratic bureaucracy to drive decision making. In contrast to the ideal-type Weberian bureaucracy, the reality is that relations between politicians and the bureaucracy vary markedly in practice (Dasandi \& Esteve, 2017). Bureaucracies are not merely rational, technocratic actors, but are motivated by their own organisational interests and entrenched ideas about how things should be done. Moreover, the degree to which technical expertise is developed and prioritised (or marginalised and undermined) in decision making is ultimately an inherently political outcome (Migdal, 1988, 2001; Grindle, 2012). 
While technical input into decision making is essential, past research has highlighted the dangers of an overly empowered technical bureaucracy or technocracy. ${ }^{2}$ Examples abound, particularly in relation to dam building, of politically and economically powerful agencies dominated by a particular scientific or engineering worldview pursuing projects to control nature and re-engineer society as 'an end in itself, rather than a means to an end' (Molle et al, 2009, p 328; Reisner, 1993; Scott, 1998). As such, effective planning in the electricity sector requires a delicate balance of relations, with politicians supporting the technocracy and prioritising technical expertise in decision making, while maintaining control of strategic vision and oversight of the sector (Lavers \& Dye, 2019).

This framework is applied using a process-tracing methodology (George \& Bennett, 2004; Bennett \& Checkel, 2014), that is used to reconstruct the decision-making process on electricity-generation planning over the period of rule by the Ethiopian Peoples' Revolutionary Democratic Front (EPRDF) (1991-2019). ${ }^{3}$ Process tracing entails the theoretically guided analysis of a sequence of events, with empirical evidence used to compare the explanatory power of competing theoretical propositions. The main source for the paper is more than 100 key informant interviews conducted between June 2018 and March 2020 with many of the key politicians, technocrats, consultants and donor officials involved in the sector (see Annex 1). These qualitative data were then triangulated with official data and reports.

We argue that the electricity sector is emblematic of the successes and failures of the EPRDF's developmentalism. For the EPRDF, the expansion of electricity generation was a central pillar of the national development strategy and a means of legitimating EPRDF rule through the delivery of progress. Electricity was seen as a key input into the ultimate goal of industrialisation, a necessity for structural transformation, and as a means of securing foreign exchange. The overwhelming focus of this push to expand electricity has been a dam boom that is based on a distinctly 20th-century model of state investment. Ethiopia has long rejected the 'standard model' for the electricity sector involving unbundling, liberalisation and privatisation, as well as bypassing the complexities of private finance. Instead, inspired by a bricolage of influences ranging from a Marxist-Leninist tradition within the party and a more recently articulated 'developmental state' ideology, Ethiopia's dam building programme has been a state-led, debt-financed affair. This strategy has, in many ways, been remarkable, with a major increase in generation capacity and several eye-catching megaprojects. However, the overly ambitious and implausible targets for hydropower generation have also had detrimental impacts on the sector. Notably, these include a focus on headline-grabbing new generation rather than maintenance and stability of the existing system; a narrow focus on installed capacity over energy generation; and the accumulation of massive debts that have played a major role in Ethiopia's current fiscal crisis.

\footnotetext{
${ }^{2}$ For the most part, this literature focuses on the bureaucracy. In this paper, we use the term 'technocracy', in acknowledgement of the technical and scientific expertise of the officials in the electricity sector, in contrast to the general administrative role implied by 'bureaucracy'.

${ }^{3}$ The EPRDF was dissolved in 2019 with most of its constituent parties merging to form the current ruling party - the Prosperity Party - while the Tigrayan People's Liberation Front (TPLF), which founded the EPRDF, left the coalition and, at the time of writing, is embroiled in a civil war with the federal government. These recent events are beyond the scope of the present paper.
} 
The paper is organised into four main sections and a conclusion. The first sets out the political economy dynamics shaping national development strategies and the role of electricity within them over nearly three decades of rule by the EPRDF. The second examines relations between the political leadership and the technocracy, highlighting the subordinated status of the technocracy, which limits technical input into decision making. The third looks in detail at the strategic decision-making process for the electricity sector, with a particular focus on the setting and evaluation of generation targets. The fourth section evaluates the implications of these overly ambitious targets and the narrow focus on generation capacity through the marginalisation of the technocracy.

\section{Power and electricity within the EPRDF's developmental project}

The EPRDF's approach to electricity generation over recent decades has been fundamentally shaped by political dynamics within the ruling coalition and the evolving ideological commitments of key political figures within it. This section outlines these key political shifts and how they have shaped the approach to the sector. The importance of electricity is a valence issue acknowledged by government and donors throughout the EPRDF era. Nonetheless, the need to expand generation and supply of electricity has been justified explicitly in ideological terms, which, in turn, has shaped strategies for expanding provision.

The EPRDF came to power in 1991 as the dominant partner in a transitional government and has governed alone since it won the first national elections in 1995. The EPRDF originates in the Tigrayan People's Liberation Front (TPLF), which fought a Maoist insurrection against the previous Derg regime (1974-91), mobilising the population of Tigray along ethno-national lines. The TPLF then established the EPRDF as a coalition of parties to represent Ethiopia's ethnic groups. While formally all four EPRDF parties carried equal weight within the coalition, the TPLF exerted disproportionate influence, particularly early on. Coming to power shortly after the fall of the Berlin wall, the EPRDF sought to downplay its socialist history (Berhe, 2008). Nonetheless, socialist ideology remained a prominent influence in the early years of its administration.

The TPLF's socialist roots were an important influence on the EPRDF's approach to the electricity sector. ${ }^{4}$ One former TPLF central committee member recalls that, within the EPRDF, electricity "was seen as life and death", citing the influence of Lenin's thinking: ${ }^{5}$

Communism is Soviet power plus the electrification of the whole country. Otherwise the country will remain a small-peasant country ... Only when the country has been electrified, and industry, agriculture and transport have been placed on the technical basis of modern large-scale industry, only then shall we be fully victorious. (Lenin, 1920)

Party programmes from the civil war onwards repeatedly noted that electricity and other key economic sectors should remain "under state control" in the interests of creating a self-reliant economy free of "imperialist" influence (TPLF, 1983, p 11; EPRDF, 1993). Shortly after taking power, EPRDF documents reasserted that "imperialism and the comprador class"

\footnotetext{
${ }^{4}$ Indeed, the ideologies that shaped 'Lenin's Light' have influenced other regimes and their approach to electrification (Sneath, 2009; Collier, 2011).

${ }^{5}$ Interview with former TPLF Central Committee Member (EG46).
} 
were "enemies" of the Front, while the national bourgeoisie was an untrustworthy "vacillating force" (EPRDF, 1993). The EPRDF therefore retained all electricity generation, transmission and distribution under state control, while foreign investors "should never be allowed to involve at any scale in basic services such as telephone, electricity, train transport, etc" (EPRDF, 1993). ${ }^{6}$

A major split in the TPLF in 2001 is widely acknowledged as a key juncture in the trajectory of the EPRDF and Ethiopian politics more broadly. The split was sparked by a power struggle between the then prime minister, Meles Zenawi, and the TPLF leadership, based in Mekele, and a debate over the handling of the Eritrean war (1998-2000) (Milkias, 2003; Tadesse \& Young, 2003). In retrospect, the split and the victory of Meles' faction led to a shift away from the previous system of collective leadership towards increased centralisation of power under the prime minister. The split led to the removal of many among the left wing of the party, while Meles charted a different direction thereafter (Milkias, 2003; Tadesse \& Young, 2003; Lefort, 2012). This intra-elite conflict had implications for the trajectory of the party's economic outlook and approach to electrification. As one TPLF Central Committee member remarked:

The splits were not over real policy issues; it was on tendencies. One group saw the other as lenient, subservient, capitalist (working for capitalists), while the other had views of the counterpart as diehard, socialist and leftist. ${ }^{7}$

For the first time, the EPRDF formally embraced capitalist, rather than socialist, development as its objective (Simon, 2011). A series of strategic documents laid out the basis of what became known as Ethiopia's 'developmental state' model, drawing on the experiences of South Korea and Taiwan. The government outlined increasingly ambitious plans for the structural transformation of the economy based on massive state investment in infrastructure, promotion of agricultural and industrial production, and expansion of social services (Mol, 2002a, 2002b; MoFED, 2003). This developmental commitment was reinforced by the outcome of the highly contested 2005 elections, in which significant opposition gains briefly threatened EPRDF's dominance. The corollary of this was the closing of political space, further centralising power among a small ruling elite and doubling down on rapid development as a means of securing the compliance of the population. Consequently, rapid development was seen by the EPRDF not just as desirable, but as a necessity to avert the existential threat of poverty as part of a process of the "securitisation of development" (Gebresenbet, 2014). Moreover, the EPRDF appears to have largely dropped any pretence of drawing legitimacy from popular and contested elections, instead putting a premium on 'performance legitimacy' through economic growth and the aim of entering the group of middle-income countries (Clapham, 2018). Increased electricity generation - with some justification - was seen as essential to the pursuit of these goals and therefore to the very maintenance of the regime.

\footnotetext{
${ }^{6}$ Paulos Milkias claims that Prime Minister Meles planned to privatise the Ethiopian Electric Light and Power Authority in the 1990s but that this move was vetoed by the TPLF leadership (Milkias, 2003). This claim would seem completely at odds with all other evidence from the time and we have been unable to turn up any evidence in support of it.

${ }^{7}$ Interview with former TPLF Central Committee Member (EG46).
} 
The expansion of electricity generation and access through low-tariff supply was seen as vital to the 'developmental state' agenda, with rural electrification contributing to the agriculture-focused development strategy (MoFED, 2003) and cheap electricity subsidising industry and promoting investment (Mol, 2002a) and underpinning the plans for an electrified national railway network (Terrefe, 2018; Rode et al, 2020). Though initially focused on domestic energy requirements, ambitions quickly grew. The possibility of Ethiopia exploiting its considerable potential for hydropower to export to neighbouring countries had been identified since the 1960s (USBR, 1964; WAPCOS, 1990). Under the EPRDF these ambitions were expanded significantly, with electricity exports increasingly seen as a means of compensating for slower than expected growth in industrial exports and of addressing growing foreign exchange shortages. ${ }^{8}$

While the embrace of the 'developmental state' meant some opening up to the private sector, the EPRDF remained deeply sceptical. Just as the national bourgeoisie had long been considered a vacillating force, under the 'developmental state' the private sector was divided into two: on the one hand, 'parasitic' rent seekers who should be suppressed and, on the other, partners in the government's developmental project, who should be supported (EPRDF, 2010a, p 7). While private investors were thus technically allowed to generate electricity and sell to the Ethiopian Electric Power Company (EEPCo) from 2002 onwards (FDRE, 2002), this was discouraged in practice. A key means of promoting electricity access for rural users and subsidising industrial investment was to provide very low tariffs that effectively excluded for-profit investment in generation. ${ }^{9}$ Plans for expansion entailed massive state investment in hydropower as the least expensive and most abundant source of power, along with grid expansion to expand access and maintain state control over tariffs. $^{10}$

The focus on expanding hydropower through state investment was a longstanding agenda of the party, but was easily couched within a growing global debate in the late 2000 s about renewable energy sources, sustainability and climate change. Reflecting his growing regional and global profile, Meles Zenawi was selected to speak on behalf of Africa at the Copenhagen Summit, clearly articulating the view that, since Africa had made the least contribution to climate change and is likely to suffer the most from it, it should be compensated by those responsible for large-scale emissions. A key feature of this narrative was that Ethiopia was charting a distinct, low-carbon development path based on hydropower:

We plan to sustain our current double digit rates of growth for the next 15 years so that by 2025 we become a middle income country. We plan to do so in a manner that would allow us to have zero net-carbon emissions by 2025. (Zenawi, 2009)

However, the Ethiopian strategy, outlined in the 2011 Climate Resilient Green Economy strategy (FDRE, 2011), appears to have been largely based on the resources available to

\footnotetext{
${ }^{8}$ Interview with former EPRDF Minister (EG44).

${ }^{9}$ Interview with a senior official in the energy sector (EG13).

${ }^{10}$ The almost exclusive dominance of hydropower in Ethiopia's energy mix and the recent turn to nonhydro renewables is the subject of discussion in a separate forthcoming paper that examines the energy mix and role of private sector investment.
} 
Ethiopia. For countries without fossil fuel deposits, "carbon based energy resources are going to be prohibitively expensive even before they make our planet unlivable [sic]", while "we are richly endowed with green and renewable sources of energy ... [including] huge hydro power and wind power potential" (Zenawi, 2015). Thus, Ethiopia's focus on renewable energy was also easily justified financially, beyond any ideological commitment to sustainability.

The EPRDF's dominance and growing recognition of Ethiopia's economic successes were threatened by the death of Meles - undoubtedly the dominant figure in national politics - in 2012. While the regime was initially successful in presenting an image of continuity and stable succession, the reality of rapid fragmentation among political elites within the coalition became more apparent over time. Meles' successor as prime minister, Hailemariam Dessalegn, was in reality little more than a compromise candidate, seen as a relatively neutral choice as a member of the Southern Ethiopian People's Democratic Movement (SEPDM), the weakest EPRDF party, by the three most influential EPRDF parties, the TPLF, the increasingly assertive Amhara National Democratic Movement (ANDM) and the Oromo People's Democratic Organization (OPDO). The 2012 appointment of three deputy Prime Ministers from these three more powerful parties was an attempt at balancing these competing coalition partners. The apportionment of the ministerial positions as the outcome of intra-elite bargaining was central in shaping the modalities and dynamics of the electricity sector.

The key figure for the electricity sector was Dr Debretsion Gebremichael, deputy prime minister for the finance and economy cluster. He was an emerging figure in the TPLF, who became deputy chair of the front after Meles' death in 2012 and is widely believed to have had close links with the military and intelligence services. Despite the growing fragmentation within the ruling elite as a whole, Debretsion managed to exert enormous influence over the electricity sector, particularly through his role as chair of the board of the state power company. There was considerable continuity in strategy under Hailemariam's administration, with continued touting of the 'developmental state' and the deification of Meles Zenawi. Yet, rupture was also evident in the growing focus on foreign investment as the means of promoting structural transformation and, from 2016, acceptance of the limits of debt-financed state investment. ${ }^{11}$ The extent to which this change represents a change in ideological approach or merely the acceptance of the hard constraint of debt is unclear. Nonetheless, the government has increasingly accepted private finance and investment in areas previously reserved solely for the state, including electricity, from around 2015/16.

Donor influence over the electricity sector had been modest until 2016. As others have observed, the Ethiopian government fought to preserve considerable autonomy in decision making from donor influence (Borchgrevink, 2008; Furtado \& Smith, 2009; Feyissa, 2011; Hagmann \& Reyntjens, 2016). This general trend was exemplified by the electricity sector. Given its ideological commitments, the EPRDF was resistant to foreign influence over the sector. ${ }^{12}$ The government also found it increasingly hard to find concessional lending for dam

\footnotetext{
${ }^{11}$ These events are discussed in more detail in a separate forthcoming paper on the energy mix and the role of private sector investment.

12 Interview with donor representative (ED16).
} 
projects after Gilgel Gibe I (World Bank) and Gilgel Gibe II (Italian government), as Western donors became increasingly reluctant to get involved in frequently controversial projects. ${ }^{13}$ In particular, the Gilgel Gibe III dam provoked controversy regarding its downstream impacts on livelihoods and the environment in Ethiopia and neighbouring Kenya (Verhoeven, 2013; Hailu Woldegebrael, 2019). The government's resistance to donor involvement in the sector has only changed relatively recently, as state investment has been limited by debt burdens and donors - notably the World Bank and USAID - have seized the political opening, using funding to promote liberalisation and private sector involvement.

\section{Political ambitions and technical expertise in the electricity sector}

Despite embracing the idea of a 'developmental state', the EPRDF approach to policy making differs markedly from the picture of a politically empowered technocracy that is attributed such importance in the developmental successes of East Asia (Johnson, 1982; Amsden, 1992; Evans, 1995). Meles' own writing highlighted the importance of state autonomy, alongside developmental vision, as key components of a developmental state (Zenawi, 2012). Yet the need for autonomy to protect against political capture is just one aspect of these successful bureaucracies. Key EPRDF and government documents (EPRDF, 2006, 2010b) are silent on other aspects, such as the importance of meritocracy and political empowerment of the bureaucracy, as others have highlighted (Lefort, 2013; Chang \& Hauge, 2019; Gebresenbet \& Kamski, 2019). In contrast, the EPRDF, from its inception to its disintegration, cast itself as a vanguard party tasked with mobilising and raising the consciousness of the masses under a framework of revolutionary democracy and democratic centralism (EPRDF, 1993, 2010a). Under democratic centralism, debate and discussion is encouraged within party structures but, once the vanguard comes to a decision on the way forward, this decision is considered binding on all. The tension between topdown political direction and the prioritisation of technocratic expertise is clear.

Moreover, after taking power in 1991 the EPRDF confronted a bureaucracy that was largely resistant to the Tigrayan-dominated movement that had seized power through force. An inimical relationship between the party and the bureaucracy was established based on the dominant view that the latter was a hotbed of 'bureaucratic capitalism', whereby public office was a route to self-enrichment (EPRDF, 1990). The antagonistic nature of initial relations was noted by Vaughan and Tronvoll (2003, p 94), who recall that during the transitional government of the early 1990s:

many EPRDF officials openly expressed the view that the "moribund" civil service was "the next enemy we have to fight now that we have overcome the Dergue".

Other observers agreed:

The bureaucracy was seen as essential to governing the country, but also a barrier to progress and reform. The result was that the EPRDF vanguard saw its role as controlling and pressurising the bureaucracy to adhere to the front's directives. (De Waal, 2015),

\footnotetext{
${ }^{13}$ The Chinese state has subsequently become an important source of finance for infrastructure, including hydropower projects, beginning with the Tekeze dam.
} 
"Through policies, supervision, monitoring and through pressure, so somehow the bureaucracy will split into those who will really cope up with the system, and those who will not cope up. And that is a long process." (TPLF officials, cited in Weis, 2015)

To dominate the civil service, many EPRDF fighters were rapidly trained as civil servants through the Civil Service College and placed as trusted individuals into key positions, including leading many state enterprises (Vaughan \& Tronvoll, 2003). Furthermore the system of gimgema, which the TPLF had used as a means of accountability and discipline during the civil war, was extended to the civil service as a whole (Berhe, 2020). Gimgema is a process of critique and self-critique undertaken by individuals in front of their superiors and subordinates. While it may have some potential as a rudimentary system of performance evaluation, it is widely viewed as a mechanism of political discipline, "a basis on which to attack, often even humiliate, those who promoted alternative viewpoints" (Vaughan, 2011, p 628). As such, it has been widely resented by the civil service.

In addition, the government has sought to ensure the political loyalty and ideological commitment of the bureaucracy by requiring party membership of many new recruits, organising civil servants into 1-to-5 networks making up a 'change army', in which one leader instructs five followers (World Bank, 2017), and using these structures to pursue political education through training sessions and distribution of pamphlets and other party propaganda (Vaughan \& Tronvoll, 2003; Fourie, 2012; Weis, 2015). As such, rather than empowering the bureaucracy to direct strategies based on technical expertise, the approach under the EPRDF has been for the political vanguard to identify political priorities and instruct a subdued civil service on their implementation, while enforcing upward accountability to political leaders. ${ }^{14}$

The retention of all electricity generation in state hands until very recently has meant that this state apparatus is central to delivering the politically prioritised expansion of electricity infrastructure. Ethiopia has - to date - resisted any substantial move towards what has been termed the 'standard model', promoted particularly by the World Bank and entailing: unbundling of generation, transmission and distribution into separate entities overseen by a regulator; the promotion of private sector involvement through Independent Power Producers (IPPs); and market liberalisation and competitive pricing (World Bank, 1993; Gore et al, 2019; Lee \& Usman, 2019). The state-owned Ethiopian Electric Light and Power Authority (EELPA) was established in 1956 and covered all aspects of electricity from generation to distribution. In 1997, EELPA was split into the Ethiopian Electric Power Company (EEPCo) and the Ethiopian Energy Authority on the advice of the World Bank (World Bank, 1996, p x). While the Bank wanted further reform at this stage, the government was "ardent and unyielding on privatisation", telling the Bank "this is the extent we can go and if that is not enough then we don't want your money". ${ }^{15}$ In reality, the reforms were little more than aesthetic. EEA was widely regarded as a toothless regulator, dwarfed in influence by EEPCo and the political leadership. Meanwhile, electricity tariffs were deliberately set low as "charity", ${ }^{16}$ which meant that EEPCo - tasked with making massive investments in

\footnotetext{
${ }^{14}$ For similar dynamics in the sugar sector, see Gebresenbet and Kamski (2019).

${ }^{15}$ Interviews with senior official in the energy sector (EG6) and a former senior EEP official (EG8).

${ }^{16}$ Interview with a senior official in the energy sector (EG37).
} 
generation and transmission - could not possibly operate as a corporatised state enterprise, its supposed remit.

In 2013, EEPCo was further split into Ethiopian Electric Power (EEP) - responsible for generation and transmission -and the Ethiopian Electric Utility (EEU) - responsible for distribution. This reform was at the initiative of the government, intended to promote greater attention to distribution, ${ }^{17}$ which had been neglected under EEPCo. The reform was actually questioned by the World Bank at the time. ${ }^{18}$ The division has proven problematic in many respects, ${ }^{19}$ but it did not change the state-led focus of energy generation. The electricity sector falls under the Ministry of Water, Irrigation and Electricity (MoWIE), reflecting the dominance of hydropower in generation. MoWIE is responsible for river basin planning, overseeing dam feasibility studies and setting broad priorities for the sector, such as the energy mix, while EEP is responsible for planning electricity generation and investing in new projects.

Despite this formal division of power, in practice decision making on electricity has been highly centralised in line with the political dynamics discussed in the previous section. Before 2012 all key strategic decisions on power projects were made by Prime Minister Meles. After Meles' death, Debretsion took an outsized role in the sector as deputy prime minister for finance and economy, with responsibility for formulating the economic part of the national development strategy (the Growth and Transformation Plan II), and chair of the EEPCo and then EEP boards. The result was that Meles and subsequently Debretsion and a few other key politicians and their senior advisors have been the main decision makers in the sector, while EEPCo/EEP management have essentially been reduced to implementing politically defined targets. ${ }^{20}$ As one long-term official in MoWIE noted:

Decisions are made by government, with details on number of connections and generation capacity ... When it comes to enforcing these decisions, the Board has more power than the executive management [of EEP]. The Board meets weekly, sometimes daily. The executive managers act more like line managers, they are not that powerful. ${ }^{21}$

Or as another EEP official put it: "Ethiopia's politicians decide for the engineers". ${ }^{22}$ These decision-making dynamics and the subordination of technocrats to politicians have shaped the target setting, planning and implementation of a number of generation and transmission projects.

\section{Delivering development: targets, ambition and incentives}

The preceding sections have demonstrated that the electricity sector has been a central portfolio for the EPRDF, as an engine of economic growth, public legitimacy and political power. Meanwhile, a subordinated technocracy has been tasked with delivering the politically defined objectives with relatively little influence over the nature of these goals. In

\footnotetext{
17 Interviews with senior officials in the energy sector (EG6, EG8, EG9, EG37).

18 Interview with a donor representative (ED16).

19 Discussed in a separate forthcoming paper on bureaucratic capacity.

${ }^{20}$ Interview with a former official in the energy sector (EG2).

${ }^{21}$ Interview with a former official in the energy sector (EG2).

22 Interview with senior official in the energy sector (EG9).
} 
this section, we trace these shifting institutional configurations, ever-rising developmental ambitions and the underlying political economy to the target-setting and decision-making processes within the electricity sector itself.

Ever since the EPRDF came to power in 1991, it has faced the challenge of rapidly increasing electricity generation. In the early 1990 s total installed capacity supplying the grid was just $370 \mathrm{MW}$, while just $4 \%$ of the population, almost exclusively urban, was connected to the grid (World Bank, 1996). Economic recovery in the early 1990s meant that demand rapidly outpaced the limited supply, while periodic droughts disrupted hydroelectric power generation, exacerbating the problem (World Bank, 2006).

The formal planning process in the electricity sector is based on the periodic Power Sector Masterplans produced by EEPCo/EEP. These masterplans model future demand based on current usage and expected growth, and propose a sequencing of projects, based on existing feasibility studies, to meet that projected demand. National development plans are expected to take these masterplans and set targets for EEPCo/EEP to meet based on these projections. For instance, EEPCo produced a Power Sector Masterplan in 2000-03, which formed the basis of targets in the Sustainable Development and Poverty Reduction Programme (SDPRP) of 2002-05 (MoFED, 2002). In retrospect, that initial strategy was relatively modest in its ambitions and the SDPRP target was met with the completion of the Gilgel Gibe I dam (184 MW) in 2004 (see Figure 1). As a former EEP official noted, the Masterplan, "planned not so big an economic growth forecast. The government acted in a different mode then."23

By the time of the next development plan, the Plan for Accelerated and Sustained Development to End Poverty (PASDEP, 2005-10), government ambitions had risen significantly. In part, this was based on the economic successes already achieved. As an economic advisor to the prime minister recalled:

we had planned for $7 \%$ per year growth and unexpectedly found growth of $10 \%$ one year [2004]. This demonstrated to us that double digit growth is possible and that it should be maintained. ${ }^{24}$

However, this belief in the possibility of rapid growth was reinforced by political dynamics at the time, notably the 2005 elections and the need for rapid growth and mass electrification to consolidate EPRDF rule. ${ }^{25}$ PASDEP targets required a near tripling of installed capacity over five years (MoFED, 2005), a target which was well beyond the demand projections in the 2006 update to the Masterplan (EEPCo, 2006). As such, this constituted a first sign of the gap between the ambitions of the political elite and the technical input from the technocracy. While no doubt challenging, EEPCo nonetheless came close to achieving this target through the completion of the long-conceived Tekeze dam (300 MW) in 2009 and the Gilgel Gibe II hydroelectric project (420 MW) in 2010.

\footnotetext{
${ }^{23}$ Interview with former EEP senior official in the energy sector (EG13).

${ }^{24}$ Interview with senior advisor to the prime minister (EG45).

${ }^{25}$ The Universal Electrification Access Programme was launched in 2005 and is discussed in a forthcoming paper.
} 
Figure 1: Installed capacity and targets during SDPRP and PASDEP, 2001-10

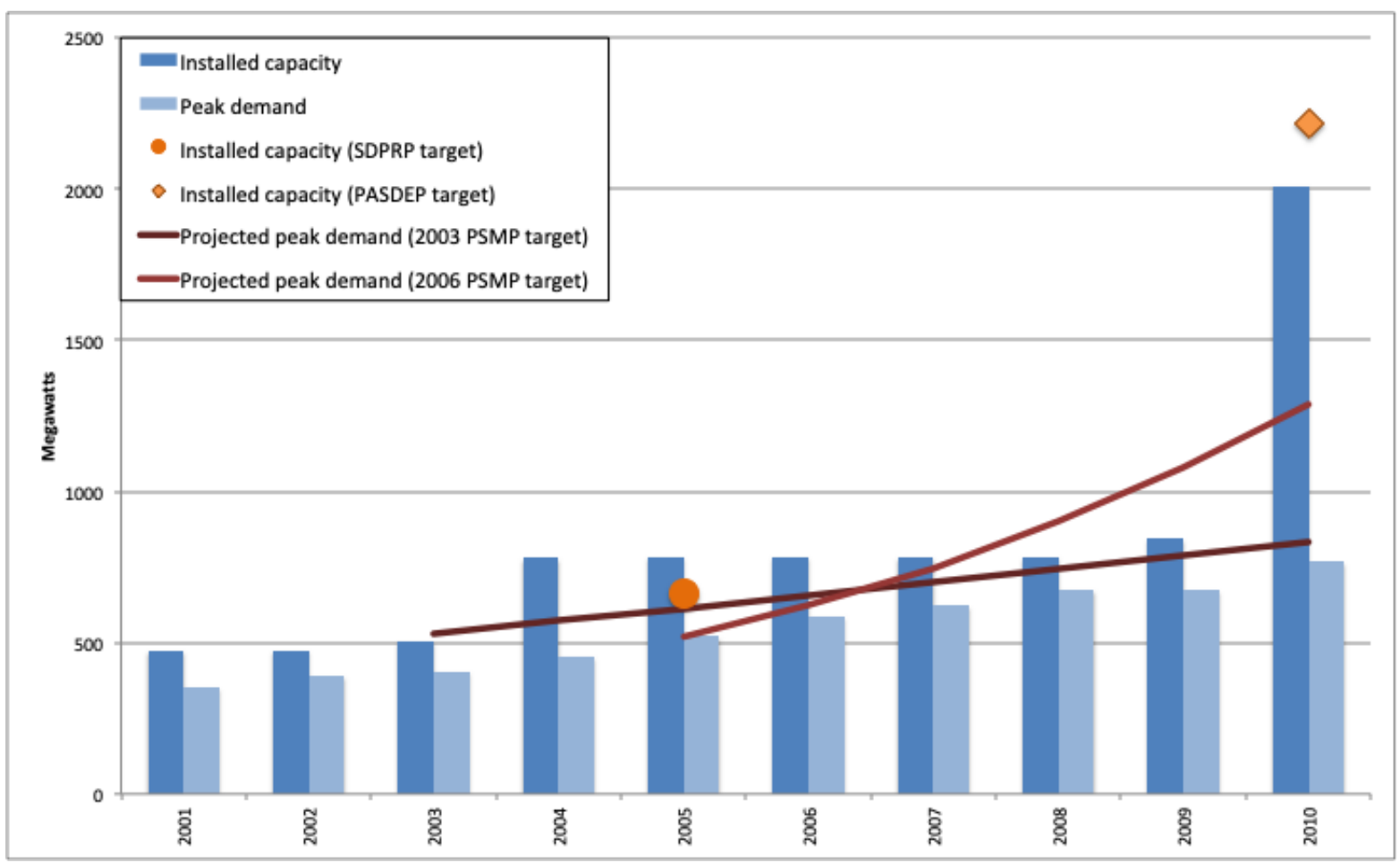

Notes: The 2003 PSMP did not set annual targets for peak demand, rather it set a target for 2012. The line on the graph is derived by pro-rating the increases between 2003 and 2012.

Sources: Acres International (2003), EEPCo (2006), MoFED (2002, 2005), USAID (2019).

The completion of these projects bought some breathing room, with installed capacity outstripping demand, albeit in the context of low access to electricity across the country. It was a temporary respite, however. One of the main architects of the national development strategies noted that the leadership felt the continual need to expand further in anticipation of ever-rising demand and the growing developmental ambitions of the government.

Demand was growing all the time. We completed one project but the demand had grown.

The only way was to overwhelm the problem - to see if that is feasible. ${ }^{26}$

The necessity of moving faster and with ever bigger projects was also clearly highlighted to a key contractor involved in several projects in this period:

The idea was growth linked to electricity, energy. I don't know where they [the government] got the figure from but they always talked about $17 \%$ annual growth of demand of energy and they wanted to anticipate that growth. ${ }^{27}$

In the mid-2000s, however, the objective of electricity generation moved beyond merely meeting domestic needs, with a growing focus on becoming a major electricity exporter to address the country's growing foreign exchange problems, and of financing the ever-growing developmental ambitions of the government. To some extent these plans were solidified by the consultative process between Egypt, Ethiopia and Sudan that attempted to pursue a

\footnotetext{
${ }^{26}$ Interview with a former minister (EG44).

${ }^{27}$ Interview with a private contractor in the energy sector (EP12).
} 
hydropower project on the Blue Nile under the auspices of the Nile Basin Initiative (NBI). The $\mathrm{NBI}$ commissioned a study in 2006-07 that established the basic feasibility and principles of electricity trade with Sudan and Egypt in an attempt to promote a win-win deal between the countries (NBI ENTRO, 2008).$^{28}$ While plans for exports to Egypt remain a hope for the future, electricity exports have been established to Djibouti through a $100 \mathrm{MW}$-capacity line since 2010 and to Sudan with a capacity of $100 \mathrm{MW}$ since 2012. Discussions continue about a larger export deal with Sudan as part of negotiations on the Grand Ethiopian Renaissance Dam (GERD). Meanwhile, a Power Purchase Agreement (PPA) has been signed to export $400 \mathrm{MW}$ to Kenya from 2020, and there are ongoing negotiations regarding a 400 MW PPA with Tanzania. ${ }^{29}$ As Cuesta-Fernández (2016) has noted, the government's more ambitious plans for large-scale future electricity exports to major markets such as Egypt and South Africa face numerous technical and political challenges.

The combined result of growing developmental ambitions, the perceived need to 'overwhelm' growing demand and the desire to become a major exporter is that around the mid- to late2000 s the political leadership subverted any 'technical' process in electricity planning. The result was the cumulative imposition of ever more fanciful plans and overly ambitious targets. From this point at least, technical input into decision making appears to have been limited. The targets set during the Growth and Transformation Plan (GTP1) of 2010-15 represented a major step-change in ambition (see Figure 2). The target involved a five-fold increase in generation capacity to $10,000 \mathrm{MW}$ by 2015 and bore no resemblance to the projections of the 2006 masterplan or any other reasonable assessment of future demand. Instead the electricity target was based on meeting the projected demand of massive economic growth and expansion of industrial production, as well as the first phase construction of 2,395 $\mathrm{km}$ of railways, all envisaged in the GTP1 (MoFED, 2010). GTP1 targets across sectors proved to be unrealistic and were not achieved (NPC, 2016). This over-ambition was particularly the case for the electricity sector, whose generation targets were based on the anticipated demand requirements resulting from the successful achievement of all these other sectoral targets.

${ }^{28}$ Discussed in more detail in a forthcoming paper on attempts to build a dam on the Blue Nile.

${ }^{29}$ As with decision making in the sector more broadly, the push for electricity exports appears to have been primarily driven by the prime minister, rather than by other state agencies with potential interest, such as the Ministry of Finance. Indeed, electricity exports to Sudan are apparently based on a personal arrangement between Meles and President Al-Bashir of Sudan, with the negotiated agreement unsigned according to one well placed informant (EG14). 
Figure 2: Installed capacity and targets during GTP1, 2010-15

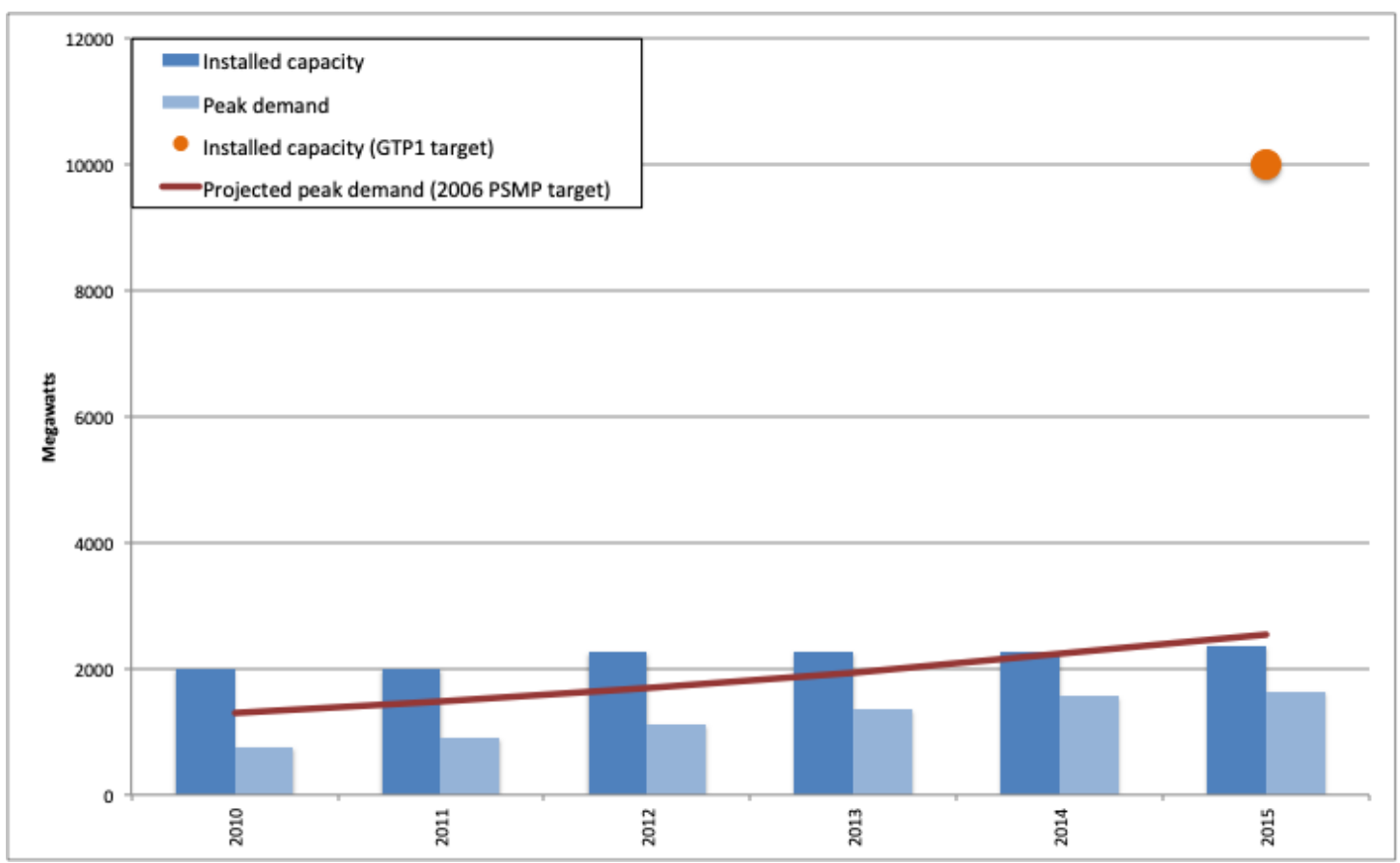

Sources: EEPCo (2006), MoFED (2010), USAID (2019).

It has not been possible to obtain a complete list of the projects originally planned to produce the additional $8,000 \mathrm{MW}$ of hydropower by the end of GTP1. However, this list would have included the Gilgel Gibe III (1,870 MW) and Beles (420 MW) hydropower projects, both of which were in process by 2010 . It seems likely that a dam on the Blue Nile was probably included, with Beko Abo (1,600 MW) the favoured candidate as the first in what was to be a cascade of dams as part of the NBI-sponsored process at that time. However, the GERD itself was certainly not among the candidate projects. GERD was only announced in 2011 and at the time of drafting GTP1, the dam was being planned in secret by a small team in MoWIE and the prime minister's office. Although the prime minister had been planning for such a project for a long time, at the drafting of the GTP1 the EEP planning team was completely unaware of what was then known as Project X. Nonetheless, GERD - originally intended to start early generation in 2015/16 - came to dominate the efforts of EEP during the implementation of GTP1. By the end of the period, Beles (2012) was the only major significant addition to generation capacity, with Gilgel Gibe III delayed beyond 2015 and GERD far from completion. ${ }^{30}$

It is also instructive that GTP1 did not set any targets on energy generation, just installed capacity. The installed generation capacity of a power plant, often measured in megawatts (MW), is the maximum amount of electricity that can be generated at any one point in time. In contrast, energy generation capacity is the amount of electricity produced over a given period of time, often measured in gigawatt-hours (GWh). Installed capacity is primarily important to generate sufficient electricity to meet peak demand at the point of the day or time of the year when demand is at its maximum. Energy generation capacity, in contrast, is

${ }^{30}$ A more detailed discussion on dams in the Blue Nile basin in general and the GERD in particular is provided in a separate forthcoming paper. 
the key factor when it comes to being able to meet the total demand for electricity yearround. Respondents were clear that installed capacity and not energy was the main priority for politicians throughout the EPRDF period. However, other national plans did at least have targets for energy, even if these were of a lower priority. In contrast, GTP1 neglected energy generation entirely in favour of a focus on installed capacity targets (MoFED, 2010). This dominant focus on installed capacity constitutes a severe limitation to the planning process, which placed comparatively little emphasis on the ability of the system to generate sufficient energy year-round to meet demand. One long-time MoWIE official made the point clearly:
The non-energy experts got hooked on installed capacity ... The energy targets played a minor role; they didn't receive so much attention. The focus was on installing as much peaking capacity as possible ... This policy making was conceived at the highest levels, it was not even in the ministry, it was the prime minister, deputy prime minister and their advisers. But most of them were not energy specialists. ${ }^{31}$

The process leading to GTP2 compounded the problems in the planning process for GTP1. A new masterplan was produced in 2014 by a foreign consultancy firm and this fed into the targets set out in GTP2 (Parsons Brinckerhoff, 2014). This masterplan included a forecast of future energy and peak demand based on an econometric model. However, the key inputs for the demand forecast were economic projections assuming the successful attainment of the targets set out in GTP1 (which had already proven far too ambitious) and even more optimistic targets set out in the draft of GTP2. As a result, the 2014 masterplan was based on an expected massive increase in demand for new industrial parks operating at full capacity, a major electric rail network and electric-powered irrigation pumps, among many other things. As an EEP official admitted:
I remember we had to push the consultants for the power sector masterplan very hard to include the GTP1 projections in their forecast. Consultants are conservative, they didn't want to, but we knew that the first question we would receive from higher levels would be "where are the GTP targets?" so we had to include $\mathrm{it}^{32}$

The consultants likewise admitted that they were forced to construct the masterplan based on what they considered, correctly as it turns out, to be unrealistic economic plans.
you cannot not use their plans. You can't argue with it ... You can't say, "we don't believe you". We presented three scenarios based on their development plan at the time. The politicians seize on the high scenario and say, "look we need to deliver this" ... We argued with EEPCo and they said "you have to do this". ${ }^{3}$

Remarkably, however, even the masterplan's projections (Figure 3) were not considered ambitious enough by the political leadership. ${ }^{34}$ Respondents were quite clear that the key figure in translating the masterplan into targets for GTP2 by this time was the Deputy Prime Minister Debretsion. Indeed, Debretsion has been quite open about the approach he was taking in doing so,

\footnotetext{
${ }^{31}$ Interview with former senior official in the energy sector (EG2).

${ }^{32}$ Interview with former senior official in the energy sector (EG8).

${ }^{33}$ Interview with consultant to the energy sector (EP11).

34 Ibid.
} 
we need to increase our generating capacity to $17,000 \mathrm{MW}$ before the end of GTP II. This target is not chosen randomly. We have set this goal with due consideration to the power requirement of a middle-income country ... although we do have another ten years before Ethiopia reaches middle-income country status, we thought that we need to make power available before reaching middle-income status, and that is why we decided to expand our capacity to $17,000 \mathrm{MW}$ in the next five years. (Debretsion, cited in Anberbir, 2017)

Several respondents from MoWIE and EEP repeated this point that, at Debretsion's insistence, the high projection for 2025 from the masterplan was shifted forward to 2020 as a target for GTP2, essentially making up for the failure of GTP1 by achieving both GTP1 and 2 within five years. ${ }^{35}$ The latest available data show peak demand in 2017 of 2,202 MW, which is on a steady, but moderate, upward trajectory (see Figure 3). As such, there is no indication that any more than a fraction of the target of $17,000 \mathrm{MW}$ is required at present or in the medium term, while the export agreements being finalised would not come close to absorbing the surplus.

Figure 3: Installed capacity and targets for GTP2

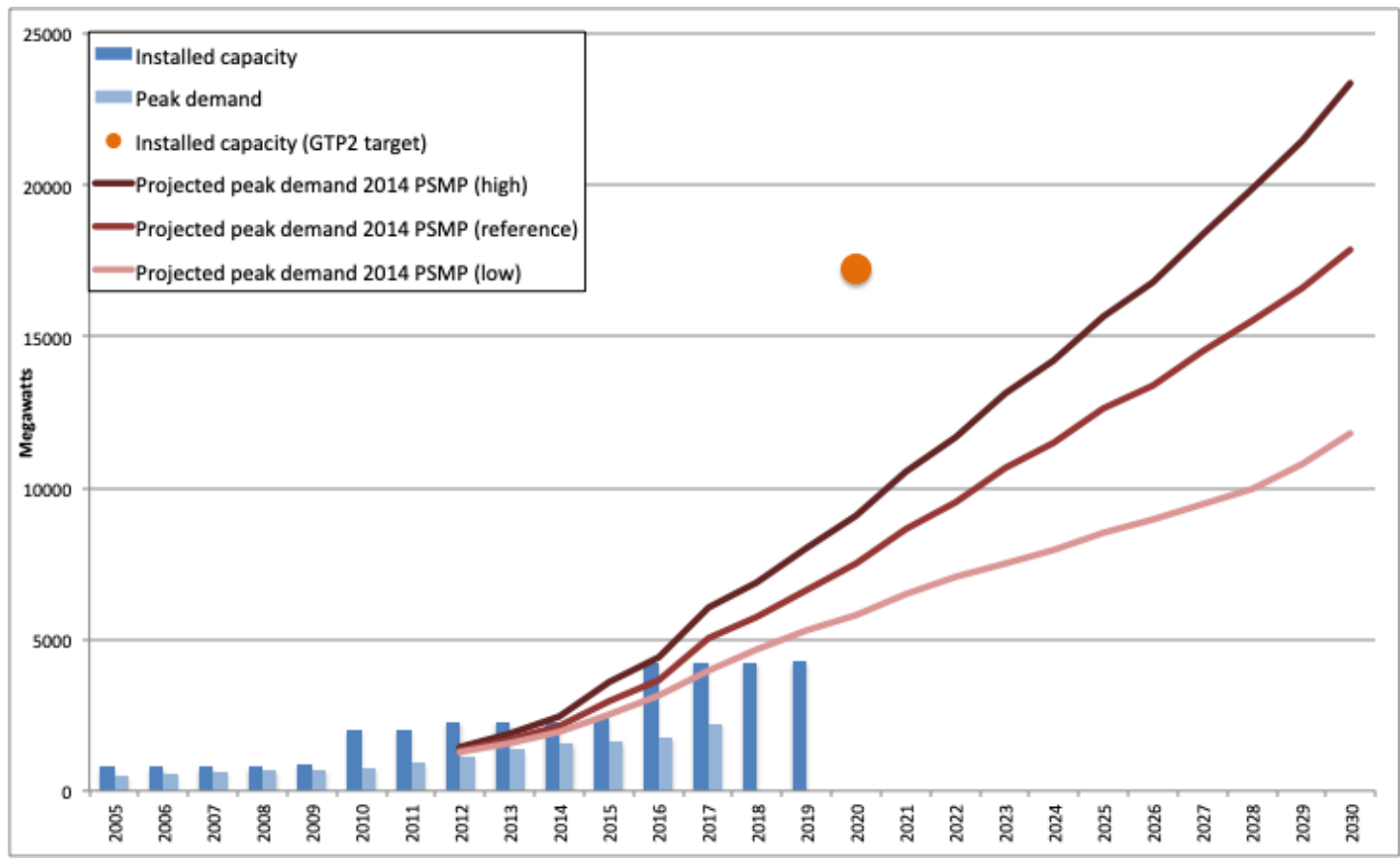

Sources: Parsons Brinckerhoff (2014), NPC (2016), USAID (2019).

As can be seen, EEP is nowhere near delivering the target for 2020. The delayed Gilgel Gibe III dam was completed in 2016, nearly doubling installed capacity in the process by adding 1,870 MW. While enormously important for national generation capacity, this barely made a dent in the GTP2 target. Indeed, even if the GERD - at one point planned to deliver 6,350 MW - had been completed during GTP2, EEP would still not have come close to meeting the target of $17,000 \mathrm{MW}$. Koysha $(2,160 \mathrm{MW})$, the fourth dam in the Gibe cascade, began construction with the completion of Gilgel Gibe III, but has been delayed by a

${ }^{35}$ Interview with former senior officials in the energy sector (EG2, EG8). 
shortage of finance and prioritisation of the GERD. In addition to these megaprojects and a range of smaller hydropower projects, GTP2 anticipated more than 3,000 MW from sources including wind, geothermal, solar, waste and sugar biomass. Little progress was made with any of these. As one donor official noted, GTP2 had truly "outrageous targets". ${ }^{36}$

This analysis therefore charts an exponential rise in ambitions from feasible, if demanding, expansion in the 2000s to a layering of ever more fantastical developmental visions under GTP1 and 2. This decision-making process was clearly driven by a handful of individuals among the political vanguard, entirely bypassing the technical and planning expertise that existed in EEP and MoWIE.

\section{Developmental vision and the perils of excessive ambition?}

The vanguard of the party and the centralisation of political power therefore worked to overrule, rather than politically empower, the technocracy in the electricity planning process. While the EPRDF government may have lacked this commonly noted aspect of a 'developmental state', it was certainly not lacking in another: developmental vision. Indeed, it was just this abundance of vision that overwhelmed technical input, resulting in a series of ever more ambitious plans. For the government this was intentional. While there is widespread acceptance in government that many GTP targets were likely to be missed to some degree, the general view was that it was better to aim high to provide the motivation to maximise progress. One former minister described the general approach.

Obviously, the targets were very high. Prime Minister Meles used to say "it's backbreaking", heavy investments. If we put all our efforts in, we will approach our targets, even if we don't reach them. We will have created a foundation that we can subsequently make a big jump. Lowering the targets to our capacity would require less motivation. Pushing ourselves, that is the philosophy. (Cited in Terrefe, 2018, p 58)

Likewise in the energy sector, EEP was informally told to "plan for $100 \%$ [achievement of the targets] but $60 \%$ is good". ${ }^{37}$ There is nothing necessarily wrong with ambition and, indeed, ambitious goals are surely a key component of any process of rapid state-led development. The challenge is that the targets during the GTP period became not just ambitious, but implausible, resulting in a number of negative impacts.

The first of these is that the power sector masterplans quickly became meaningless and offered no basis for accurately forecasting future demand for electricity or generation capacity. This point was underscored by one influential advisor in the sector: "with models it is garbage in, garbage out ... There were wrong assumptions and political pressure to go big". ${ }^{38}$ Consequently, the flawed masterplans undermined effective electricity planning. Moreover, several EEP and donor respondents noted that the lack of accurate forecasting impeded the government's ability to secure finance for projects, since lenders were put off by the unreliability of the data. ${ }^{39}$

\footnotetext{
${ }^{36}$ Interview with a donor representative (ED9).

${ }^{37}$ Interview with former senior official in the energy sector (EG13).

${ }^{38}$ Interview with a consultant to the energy sector (ED4).

${ }^{39}$ Interviews with a former senior official in the energy sector (EG8) and a donor representative (ED1).
} 
A second issue is that the government's ambitions have influenced the design of hydropower projects. As noted above, the government focused heavily on installed capacity, rather than energy generation in its plans. While installed capacity is important in ensuring that generation can meet peak demand, total and firm energy generation are also key features of a power plant. Energy is what industry, railways and households require, while installed power capacity is merely the potential to produce it. Meanwhile, the energy production potential of a dam is determined by two factors, the water flow through turbines and the head - the difference in water elevation between the reservoir and the turbines. Put differently, energy generation is the result of the hydrology of the site, the physical barrier that impounds a certain amount of water and how it is operated. Adding installed capacity to a particular project merely enables a plant to generate a large amount of energy in a short time but at the expense of the long-term total. This flexibility can be important, since it enables a dam to meet peak demand for electricity. Indeed, hydropower in many countries is used to generate peaking power given its relatively high ramp rate, or the flexibility to match changing demand. In such circumstances, the plant load factor of the dam will be relatively low, ${ }^{40}$ since the dam is used to its maximum capacity only during times of peak demand. Ethiopia, however, is almost exclusively reliant on hydropower for both baseload and peaking power. The result is that adding installed capacity to a dam with a fixed energy potential merely adds generation capacity that is not being used for most of the time. This makes energy generation more expensive overall, while enabling energy generation at high rates, resulting in reservoirs being run down.

Indeed, the political pressure to maximise national generation capacity through targets in national development plans influenced the design of individual dams, with pressure to increase their installed capacity. The same political elites that drove the national planning process were also responsible for selecting individual projects and pushing for the maximisation of installed capacity, largely bypassing technical expertise in EEP and MoWIE. While MoWIE undertakes feasibility studies for hydropower projects and EEP uses these to propose a list of projects to meet ambitious development targets, the decisions to pursue Gilgel Gibe II, Gilgel Gibe III, Koysha and the GERD were all taken by the Prime Minister's Office in discussion with the contractor for these projects, Salini Construttori. ${ }^{41}$ These new projects were outside the plans developed by EEP and MoWIE and the decision to proceed was made apparently without the knowledge of EEP leadership. While the secrecy surrounding the planning process for the GERD might explain the decision making for that project, respondents insisted that this process was typical of past projects also. ${ }^{42}$ In the words of one former senior official: "the PMO and the contractor had made the decision on the project, so we have to accept it", whereas in EEP, "we have no control" ${ }^{43}$ Likely aiding this process was the inclusion of targets for installed capacity in the annual performance assessments for relevant MoWIE and EEP officials. ${ }^{44}$ While it was ultimately politicians who

\footnotetext{
40 The plant load factor (or capacity factor) is the actual energy generation of a plant over a year divided by its maximum potential energy generation.

${ }^{41}$ Salini Construttori merged with Impregilo in 2012 to form Salini Impregilo. The firm rebranded itself in 2020 as WeBuild.

${ }^{42}$ Interviews with former senior officials in the energy sector (EG2, EG8).

${ }^{43}$ Interview with a former sector official in the energy sector (EG13).

${ }^{44}$ Interviews with former senior officials in the energy sector (EG2, EG12).
} 
made key decisions on the design of particular dams, inflating the installed capacity of a particular dam would have helped technocrats make progress towards their challenging performance targets, probably undermining the incentive to resist political pressure.

Several respondents at MoWIE, EEP and independent contractors reiterated the point that politicians repeatedly pressed them to increase the installed capacity of dams. One senior MoWIE official lamented that

in this country there is a misconception, they [politicians] look at the size in terms of MW and assume that big MW is what matters. There is this misconception amongst the politicians. By increasing the installed capacity they have just increased the unit cost of the energy. ${ }^{45}$

Equally, a long-time contractor in the sector involved in several projects noted:

The idea throughout was to maximise the MW of a single project ... The focus was on maximising power generation - the installed capacity in MW. This was the decision of the highest levels. ${ }^{46}$

As Table 1 shows, the main hydropower projects undertaken in the past decade have been adapted from the original feasibility studies that balanced installed capacity and energy generation, with a view to maximising the plant factor. In each case, revisions significantly increased the installed capacity of the dams, resulting in a series of dams with low plant factors. Indeed, most dams are able to produce energy at maximum capacity for little more than one-third of the time. Respondents were quite clear that in each case - for Gilgel Gibe 3 , Beles, Koysha and the GERD ${ }^{47}$ - the installed capacity was increased at the insistence of the political leadership. The design of the GERD has a particularly complex story, involving several revisions of the dam design. ${ }^{48}$ However, it is worth noting that, while several commentators have registered surprise that the plant factor for the dam is low, it is by no means exceptional among Ethiopia's dams. In fact, it is typical of a much broader pattern of decision making driven by politicians over technical expertise: "The politicians like big figures. They want to show the big changes they have achieved. It is the same with all the dams." 49

At points this focus on maximising installed capacity has been questioned by contractors and consultants to the sector. One recalled asking

Why do you want so much installed capacity? They said "we want to be the power supply of Africa". That's their vision. They always wanted the maximum installed capacity

\footnotetext{
${ }^{45}$ Interview with a senior official in the energy sector (EG11).

${ }^{46}$ Interview with a private contractor in the energy sector (EP12).

47 Interviews with a former senior official in the energy sector (EG8), with a member of the original feasibility study team (EP14), with a private contractor in the energy sector (EP12) and with a senior official in the energy sector (EG11).

${ }^{48}$ The history of attempts to build a dam on the Blue Nile, including the role of another key state agency, the Metals and Engineering Corporation (METEC), in the GERD is addressed in a separate forthcoming paper.

${ }^{49}$ Interview with former senior official in the energy sector (EG8).
} 
possible. Is that a good decision? Time will tell. I cannot blame the decision. I struggled with them several times, but I didn't convince them $!^{50}$

Indeed, there is no doubt that technical officials were aware of the limitations of the dam designs, with several current and former officials in EEP and MoWIE highlighting these issues. As one foreign consultant noted, "EEPCo people must know, but they decided not to say anything". ${ }^{51}$ Indeed, EEP officials were clear that they understood the limitations but that, in a situation in which power was highly centralised, there was little space for technical input into decision making. "The technical people tried to resist but they were strongly pushed to accept." 52 While the political centralisation of decision-making power meant that technocrats undoubtedly had limited leeway, it is also important to acknowledge the complexities of their position. Politicians' demands for ever-higher generation targets translated into the massive investment of resources and prestige in EEP, in particular, through the pursuit of high-profile megaprojects. As such, there would have been strong personal and career incentives for senior officials in EEP and MoWIE to go along with these rising ambitions, irrespective of the political domination of the technocracy or the marginalisation of officials' technical expertise. As such, senior technocrats' claims to have attempted to resist politically driven targets should perhaps be viewed with caution.

Table 1: Details of key hydropower projects

\begin{tabular}{|l|l|l|l|}
\hline & $\begin{array}{l}\text { Installed } \\
\text { capacity (MW) }\end{array}$ & $\begin{array}{l}\text { Average energy } \\
\text { generation (GWh) }\end{array}$ & $\begin{array}{l}\text { Plant load factor } \\
(\%)\end{array}$ \\
\hline $\begin{array}{l}\text { Gilgel Gibe III (original } \\
\text { design) }\end{array}$ & 1,200 & 6,500 & 62 \\
\hline Gilgel Gibe III (actual) & 1,870 & 6,500 & 40 \\
\hline Beles (original design) & 220 & 998 & 52 \\
\hline Beles (actual) & 460 & 1,720 & 43 \\
\hline Border dam (NBI) ${ }^{55}$ & 1,200 & 6,011 & 57 \\
\hline $\begin{array}{l}\text { GERD (original 2011 } \\
\text { design) }\end{array}$ & 5,250 & 15,692 & 34 \\
\hline Koysha (original design) & 1,472 & 6,460 & 50 \\
\hline Koysha (current design) & 2,160 & 6,460 & 34 \\
\hline
\end{tabular}

Sources: USAID (2019), except where otherwise specified in footnotes.

\footnotetext{
50 Interview with a consultant to the energy sector (EP13).

51 Interview with a consultant to the energy sector (EP14).

52 Interview with a former senior official in the energy sector (EG8).

53 Interview with a former senior official in the energy sector (EG8).

54 Interview with a consultant to the energy sector (EP14) and Acres International (2003, p 37).

${ }^{55}$ Based on ENTRO (2007, p E3). The Border dam was to be on the site where the GERD is being built. It should be noted that the former was to be part of a cascade, with upstream dams regulating the flow into the reservoir. As such, the Border and GERD dams are not directly comparable.

${ }^{56}$ As listed in the 2014 Power Sector Masterplan (Parsons Brinckerhoff, 2014, pp 4-9).
} 
Beyond the design of the dams themselves, the prioritisation of headline-grabbing new generation has come at the expense of the reliability of the existing system. One particular area of neglect has been maintenance. In theory, the 4,300 MW of installed capacity at present should be sufficient to meet current peak demand. However, a considerable amount of this capacity is not available because of poor maintenance. The Tekeze dam, in particular, has been operating well below capacity, if at all, thanks to major problems including vibrating turbines and poor maintenance. ${ }^{57}$ As one senior EEP official noted:

we had 4,300 MW installed capacity but only $2,700 \mathrm{MW}$ was actually functioning. Maintenance is not seen as a priority, the emphasis is always on new, big projects. ${ }^{58}$

A former MoWIE official likewise said:

If I could go back and could get the authority, I would orient the finance more towards maintenance. They were starved of resources. Every cent went into new generation, that was the priority. You could say that the logic could be to expand generation and then let the other parts of the system follow. ${ }^{59}$

It was not just maintenance of generation that was neglected, but also the transmission and distribution infrastructure required to carry the electricity. For the politicians at the top, the central task was to address the generation challenge once and for all. Only once that was done could the focus shift to transmission and distribution.

The task of building dams was seen as 'burden of generations', and they decided to deal with it now. The thinking was that once this was resolved, the domestic work of transmission and distribution was taken as easier. ${ }^{60}$

In the meantime, however, this created problems. When Gilgel Gibe III was commissioned in 2016 there were insufficient sub-stations to transmit the electricity that this added to the grid (Hailu Woldegebrael, 2019), ${ }^{61}$ and some respondents believe that the capacity of the transmission system is well below the generation capacity, placing additional constraints on provision. ${ }^{62}$ Furthermore, some estimate that energy losses from transmission and distribution might be as much as $26 \%$ of total generation as a result of the poor condition of this infrastructure. ${ }^{63}$

These operational problems, ranging from the focus on generation to the neglect of transmission and distribution, also demonstrate that EEP and EEU are not profit-focused companies in any meaningful way. The main source of revenues for EEP, which is required to repay the huge loans taken in its name to finance new projects, is ultimately from tariffs collected by EEU, with EEP receiving $60 \%$ of revenues collected. Not only have tariffs been deliberately set below the cost of generating and transmitting electricity with a view to providing incentives to industry and subsidising domestic consumption but, if the

\footnotetext{
${ }^{57}$ Interviews with a politician (EG30), a consultant to the energy sector (ED4) and donor representatives (ED1, ED10).

${ }^{58}$ Interview with a former senior official in the energy sector (EG8).

${ }^{59}$ Interview with a former official in the energy sector (EG2).

$60 \mathrm{lbid}$.

${ }^{61}$ Interview with a former senior official in the energy sector (EG8).

62 Interview with a former official in the energy sector (EG2).

${ }^{63}$ Interview with senior official in the energy sector (EG9).
} 
transmission infrastructure is insufficient, EEP is unable to sell the maximum amount of electricity.

After the completion of major projects, notably Gilgel Gibe III, load shedding had for several years been limited to relatively brief periods resulting from instability in the grid, rather than from absolute shortages of generation. However, in May 2019 severe rationing measures were announced that would last up to the beginning of the rainy season in July. Officially, the crisis was blamed on inadequate rainfall. ${ }^{64}$ While rainfall may have exacerbated problems, on this occasion the shortage was not purely the result of drought, but of a combination of the following factors: poor maintenance, which meant that actual generation capacity was well below what it should be; major transmission and distribution losses, which further reduced the effective supply of electricity; and delays to the GERD. These challenges were further compounded by the operation of Gilgel Gibe III. Several EEP officials and engineers involved in the dam's construction were clear that, under political pressure, the dam's operators were instructed to use the dam 'to the maximum' in order to meet demand early in the dry season (ie after September 2018). ${ }^{65}$ The short Belg rainy season (March-April 2019) was poor, with the result that the reservoir was depleted well before the main rains began in July 2019. As one EEP official reiterated:
You also need a certain operational policy for hydro dams to maximise firm energy ... What happens is that whatever you have in the reservoir, when you have delays in new projects, they [politicians] will order the evacuation of the whole reservoir. Then you may not get rain to fill it up. That is what we are facing with Gilgel Gibe III. We cannot fill the reservoir. We told the operators to use all the water to meet current demands and then there is no rain the next year to refill it. But if we follow a policy for firm energy with demand, we are safe. ${ }^{66}$

The point here is not to dispute that the EPRDF government did not achieve major progress in the electricity sector. Installed capacity has increased more than 11 times over from just $370 \mathrm{MW}$ in the early 1990 s to $4,270 \mathrm{MW}$ at present. With the protracted construction of the GERD nearing completion and other projects in process, something approaching the massive increases envisaged in the GTPs seems likely to be finally realised and the developmental ambitions of the political elite are undoubtedly a key factor in that. However, the preceding analysis has shown that unlike in Chalmers Johnson's ideal 'developmental state', in Ethiopia the politicians reign and rule, while the technocrats are expected to implement whatever political directions they are given, regardless of whether this has technical justification or not.

\footnotetext{
${ }^{64}$ Abreham Belay, interviewed for the Ethiopian News Agency, 19 September 2019. See https://www.press.et/Ama/?p=17569\&fbclid=IwAR07hvZUcdbf6j271reZwc8fNSrdVEi1iTcYzNY7gknJnyJXD QJFjXNzX_g.

${ }^{65}$ Interviews with a private contractor in the energy sector (EP12) and with senior officials in the energy sector (EG9 and EG10).

${ }^{66}$ Interview with a senior official in the energy sector (EG14). While average energy over a year is the figure usually quoted, 'firm energy' refers to the guaranteed energy generation regardless of the interannual variability of river flow.
} 


\section{Conclusion}

Ever since taking power in 1991, the EPRDF made the expansion of electricity generation a central objective, with electricity seen as a prerequisite for industrial growth, a means of securing popular acquiescence and a source of foreign exchange earnings. Growing development ambitions have resulted in rapid progress through a series of increasingly large hydropower projects completed or nearing fruition. Yet much remains to be done. Operational generation capacity and transmission infrastructure struggle to meet the demand of those connected to the grid, with load shedding still a common occurrence. Moreover, recent estimates suggest that just $33 \%$ of the population is connected to the grid (MoWIE, 2019, p xix), while the government has plans for major industrial expansion that would significantly increase demand. As such, increasing generation capacity and expanding access remain central priorities for the government.

The analysis presented in this paper has sought to provide insight into both the successes and failures of the electricity sector in the EPRDF era. To do this, we focused on two sets of relations: those between the political elite and those between the political elite and the technocracy. Where the former are concerned, decision making in the electricity sector has been tightly centralised among a handful of key politicians and advisors. This constellation of actors and their ideological reference points have evolved over time in line with shifting elite politics more broadly. Intra-elite settlements within the TPLF/EPRDF in the early 2000s and relative stability within the EPRDF until Meles Zenawi's death enabled the government to chart a long-term strategy with its series of five-year development plans. This strategy resulted in a step change in ambition regarding electricity generation and demands for an ever-larger-scale dam building programme from the mid-2000s.

While intra-elite cohesion and developmental vision have been key to the progress achieved, they have frequently acted to marginalise technical expertise, with technocratic actors subordinated to politicians and relegated to the implementation of politically defined targets. These inimical politico-technocratic relations have a long history that originated in the EPRDF's self-identification as a political vanguard and the fraught relations with an initially hostile bureaucracy when it took power. The government's assumption has been that the bureaucracy presented an obstacle to its developmental ambitions and therefore needed to be pressured to deliver on political plans. The result has been that politicians have intervened in the electricity planning process, frequently bypassing technical expertise. The result has been to undermine planning processes, introduce inefficiency into dam design and prioritise new generation over maintenance of existing infrastructure. In many respects, the electricity sector is emblematic of the successes and limitations of EPRDF's development project as a whole.

As such, the case of electricity in Ethiopia reinforces the claim that cohesion within a developmentally oriented political elite is insufficient for state-led development. As discussed in the introduction, several recent influential works have highlighted the importance of intraelite relations for industrial policy and late development more broadly (Waldner, 1999; Doner et al, 2005; Khan, 2010). Despite the many strengths of this work, relations between political and technocratic actors are usually downplayed, on the assumption that, once elite politics sufficiently prioritises state-led development, investment in bureaucratic capacity to deliver on leaders' developmental aspirations will follow. This paper has focused on electricity 
generation, rather than industrial policy - although electricity supply is undoubtedly one key input into any industrial strategy. With this focus our findings question the view that state capacity is a straightforward outcome of elite cohesion and commitment to development, instead suggesting that political-technocratic relations are themselves an important focus of analysis. Few would contest the view that the EPRDF and, in particular, Meles Zenawi were committed to rapid national development. Yet this developmental push was driven by a narrow political elite that largely marginalised technical expertise in the electricity sector, with important negative consequences. 


\section{References}

Acres International (2003). Power Sector Masterplan Study. Addis Ababa: Ethiopian Electric Power Corporation (EEPCo).

Amsden, A.H. (1992). Asia's Next Giant: South Korea and Late Industrialization. Oxford: Oxford University Press.

Anberbir, Y. (2017). 'Nuts and bolts of Ethiopian power sector'. The Reporter [available at: https://www.thereporterethiopia.com/content/nuts-and-bolts-ethiopian-power-sector]. Accessed: 8 June 2020.

Asress, M.B., Simonovic, A., Komarov, D. and Stupar, S. (2013). 'Wind energy resource development in Ethiopia as an alternative energy future beyond the dominant hydropower'. Renewable and Sustainable Energy Reviews 23, 366-378.

Bennett, A. and Checkel, J.T. (2014). Process Tracing. Cambridge: Cambridge University Press.

Berhe, A. (2008). 'A political history of the Tigray People's Liberation Front (1975-1991): revolt, ideology and mobilisation in Ethiopia'. PhD thesis. Vrije Universiteit, Amsterdam.

Berhe, M.G. (2020). Laying the Past to Rest: The EPRDF and the Challenges of Ethiopian State-building. London: Hurst \& Company.

Block, P. and Strzepek, K. (2012). 'Power ahead: meeting Ethiopia's energy needs under a changing climate'. Review of Development Economics 16, 476-488.

Borchgrevink, A. (2008). 'Limits to donor influence: Ethiopia, aid and conditionality'. Forum for Development Studies 2, 195-220.

Chang, H.-J. and Hauge, J. (2019). 'The concept of a "developmental state" in Ethiopia'. In Cheru, F., Cramer, C. and Oqubay, A. (eds), The Oxford Handbook of the Ethiopian Economy. Oxford: Oxford University Press.

Chiyemura, F. (2019). 'The winds of change in Africa-China relations? Contextualising African agency in Ethiopia-China engagement in wind energy infrastructure financing and development'. PhD thesis. Open University, Milton Keynes.

Clapham, C. (2018). 'The Ethiopian developmental state'. Third World Quarterly 39, 11511165.

Collier, S.J. (2011). Post-Soviet Social: Neoliberalism, Social Modernity, Biopolitics. Princeton NJ: Princeton University Press.

Cuesta-Fernández, I. (2016). 'Mammoth dams, lean neighbours: assessing the bid to turn Ethiopia into East Africa's powerhouse'. In Scholvin, S. (ed.), A New Scramble for Africa? (pp. 107-124). London: Routledge.

Dasandi, N. and Esteve, M. (2017). 'The politics-bureaucracy interface in developing countries'. Public Administration and Development 37, 231-245.

De Waal, A. (2015). The Real Politics of the Horn of Africa: Money, War and the Business of Power. Bristol: Polity Press. 
Demissie, A.A. and Solomon, A.A. (2016). 'Power system sensitivity to extreme hydrological conditions as studied using an integrated reservoir and power system dispatch model: the case of Ethiopia'. Applied Energy 182, 442-463.

Doner, R.F., Ritchie, B.K. and Slater, D. (2005). 'Systemic vulnerability and the origins of developmental states: Northeast and Southeast Asia in comparative perspective'. International Organization 59, 327-361.

Dye, B.J. (2018). 'The politics of dam resurgence: high modernist statebuilding and the emerging powers in Africa'. PhD thesis. University of Oxford.

EEPCo (2006). Ethiopian Power System Expansion Master Plan Update. Addis Ababa: Ethiopian Electric Power Corporation (EEPCo).

ENTRO (2007). Pre-feasibility study of Border Hydropower Project, Ethiopia. Addis Ababa: Eastern Nile Technical Regional Office (ENTRO).

EPRDF (1990). 'Report of the 1st Congress of the EPRDF, 1983 [Ethiopian Calendar]' (in Amharic). Unpublished manuscript.

EPRDF (1993). Our Revolutionary Democratic Goals and The Next Step. Addis Ababa: Ethiopian Peoples' Revolutionary Democratic Front.

EPRDF (2006). Limat Democracy ena Abiyotawi Democracy [Development, Democracy and Revolutionary Democracy]. Addis Ababa: Birhanena Selam Printing Press.

EPRDF (2010a). EPRDF Program. Addis Ababa: EPRDF.

EPRDF (2010b). 'The Tehadso Mesmer and Ethiopia's renaissance'. Mimeo, Addis Ababa.

Evans, P.B. (1995). Embedded Autonomy: States and Industrial Transformation. Princeton $\mathrm{NJ}$ : Princeton University Press.

FDRE (2002). 'Federal Democratic Republic of Ethiopia (FDRE) - Re-enactment of the investment proclamation'. Federal Negarit Gazeta Proclamation 280/2002.

FDRE (2011). Ethiopia's Climate-resilient Green Economy: Green Economy Strategy. Addis Ababa: Federal Democratic Republic of Ethiopia.

Feyissa, D. (2011). 'Aid negotiation: the uneasy "partnership" between EPRDF and the donors'. Journal of Eastern African Studies 5, 788-817.

Fourie, E. (2012). 'New maps for Africa? Contextualising the "Chinese Model" within Ethiopian and Kenyan paradigms of development'. PhD thesis. University of Trento.

Furtado, X. and Smith, J. (2009). 'Ethiopia: retaining sovereignty in aid relations'. In L. Whitfield (ed.), The Politics of Aid: African Strategies for Dealing with Donors (pp. 131-155). Oxford: Oxford University Press.

Gebresenbet, F. (2014). 'Securitisation of development in Ethiopia: the discourse and politics of developmentalism'. Review of African Political Economy 41, S64-S74.

Gebresenbet, F. and Kamski, B. (2019). 'The paradox of the Ethiopian developmental state: bureaucrats and politicians in the sugar industry'. Journal of Contemporary African Studies 37, 335-350. 
George, A.L. and Bennett, A. (2004). Case Studies and Theory Development in the Social Sciences. Cambridge MA: MIT.

Gore, C.D., Brass, J.N., Baldwin, E. and MacLean, L.M. (2019). 'Political autonomy and resistance in electricity sector liberalization in Africa'. World Development 120, 193209.

Gray, H. (2019). 'Understanding and deploying the political settlement framework in Africa'. In Cheeseman, N., Abrahamsen, R., Khadiagala, G., Peace Media and Reidl, R. (eds), Oxford Research Encyclopedia of Politics. Oxford: Oxford University Press.

Grindle, M.S. (2012). Jobs for the Boys. Cambridge MA: Harvard University Press.

Hagmann, T. and Reyntjens, F. (2016). Aid and Authoritarianism in Africa: Development without Democracy. London: Zed Books.

Hailu Woldegebrael, E. (2018). 'The materialization of "developmental state" in Ethiopia: insights from the Gibe III hydroelectric development project regime, Omo Valley'. L'Espace Politique: Revue en ligne de géographie politique et de géopolitique 35.

Hailu Woldegebrael, E. (2019). 'The politics and materiality of a developmental state in the EPRDF's Ethiopia: a view from the Gibe III hydropower development project'. PhD thesis. University of Paris Nanterre.

Johnson, C.A. (1982). MITI and the Japanese Miracle: The Growth of Industrial Policy, 1925-1975. Stanford CA: Stanford University Press.

Khan, M. (2010). 'Political settlements and the governance of growth-enhancing institutions'. Mimeo. SOAS, London.

Kohli, A. (1999). 'Where do high-growth political economies come from? The Japanese lineage of Korea's "developmental state"'. In Woo-Cummings, M. (ed.), The Developmental State (pp. 93-136). Ithaca NY: Cornell University Press.

Kohli, A. (2004). State-directed Development: Political Power and Industrialization in the Global Periphery. Cambridge: Cambridge University Press.

Lavers, T. (2018). Taking Ideas Seriously within Political Settlements Analysis. Effective States and Inclusive Development (ESID) Working Paper 95. Manchester: The University of Manchester.

Lavers, T. and Dye, B. (2019). Theorising the Political Economy of Dams: Towards a Research Agenda. FutureDAMS Working Paper 1. Manchester: The University of Manchester.

Lee, A. and Usman, Z. (2019). Taking Stock of the Political Economy of Power Sector Reforms in Developing Countries: A Literature Review. World Bank Policy Research Working Paper Series 8518.

Lefort, R. (2012). 'Free market economy, "developmental state" and party-state hegemony in Ethiopia: the case of the "model farmers"'. Journal of Modern African Studies 50, 681-706.

Lefort, R. (2013). 'The theory and practice of Meles Zenawi: a response to Alex de Waal'. African Affairs 112, 460-470. 
Lenin, V. (1920). 'Report on the work of the Council of People's Commissars'. Seventeen Moments in Soviet History [available at http://soviethistory.msu.edu/1921-

2/electrification-campaign/communism-is-soviet-power-electrification-of-the-wholecountry]. Accessed: 9 June 2020.

Löfquist, L. (2019). 'Is there a universal human right to electricity?'. International Journal of Human Rights 24(6), 711-23..

Migdal, J.S. (1988). Strong Societies and Weak States: State-Society Relations and State Capabilities in the Third World. Princeton NJ: Princeton University Press.

Migdal, J.S. (2001). State in Society: Studying how States and Societies Transform and Constitute One Another. Cambridge: Cambridge University Press.

Milkias, P. (2003). 'Ethiopia, the TPLF, and the roots of the 2001 political tremor'. Northeast African Studies 10, 13-66.

MoFED (2002). Ethiopia: Sustainable Development and Poverty Reduction Program. Addis Ababa: Ministry of Finance and Economic Development (MoFED), Federal Democratic Republic of Ethiopia.

MoFED (2003). Rural Development Policy and Strategies. Addis Ababa: MoFED.

MoFED (2005). Ethiopia: Building on Progress. A Plan for Accelerated and Sustained Development to End Poverty (PASDEP). Addis Ababa: MoFED, Federal Democratic Republic of Ethiopia.

MoFED (2010). Growth and Transformation Plan (GTP). Addis Ababa: MoFED, Federal Democratic Republic of Ethiopia.

Mol (2002a). Industry Development Strategy of Ethiopia. Addis Ababa: Ministry of Industry (Mol).

Mol (2002b). Foreign Affairs and National Security Policy and Strategy. Addis Ababa: Mol.

Molle, F., Mollinga, P.P. and Wester, P. (2009). 'Hydraulic bureaucracies and the hydraulic mission: flows of water, flows of power'. Water Alternatives 2, 328-349.

Mondal, Md A.H., Bryan, E., Ringler, C. and Rosegrant, M. (2017). 'Ethiopian power sector development: renewable based universal electricity access and export strategies'. Renewable and Sustainable Energy Reviews 75, 11-20.

MoWIE (2019). National Electrification Program 2.0: Integrated Planning for Universal Access 'Lighting to all'. Addis Ababa: Ministry of Water, Irrigation and Energy.

NBI ENTRO (2008). Eastern Nile Power Trade Program Study. Addis Ababa: Nile Basin Initiative, Eastern Nile Technical Regional Office.

NPC (2016). Growth and Transformation Plan II (GTP II). Addis Ababa: National Planning Commission (NPC), Federal Democratic Republic of Ethiopia.

Parsons Brinckerhoff (2014). Ethiopian Power System Expansion Master Plan Study: Final Report. Addis Ababa: Ethiopian Electric Power (EEP). 
Reisner, M. (1993). Cadillac Desert. New York: Penguin Books.

Rode, P., Terrefe, B. and da Cruz, N.F. (2020). 'Cities and the governance of transport interfaces: Ethiopia's new rail systems'. Transport Policy.

Scott, J.C. (1998). Seeing Like a State: How Certain Schemes to Improve the Human Condition have Failed. London: Yale University Press.

Simon, B. (2011). Ye-hulet Merchawoch Weg: Nadan Yegeta Hagerawi Rucha [A Tale of Two Elections: A National Endeavour to Put a Stop to an Avalanche]. Addis Ababa: Mega Enterprise.

Sneath, D. (2009). 'Reading the signs by Lenin's light: development, divination and metonymic fields in Mongolia'. Ethnos 74, 72-90.

Tadesse, M. and Young, J. (2003). 'TPLF: reform or decline?'. Review of African Political Economy 30, 389-403.

Terrefe, B. (2018). 'The renaissance railway: infrastructure and discourse in EPRDF's Ethiopia'. MPhil thesis. University of Oxford.

TPLF (1983). People's Democratic Programme of the Tigray People's Llberation Front (TPLF). Mekele: TPLF.

USAID (2019). Grid Management Support Program: System Integration Study (GMSP-SIS) Power Africa. Washington DC: USAID.

USBR (1964). Land and Water Resources of the Blue Nile Basin, Ethiopia. Vol. 1. Washington DC: United States Department of the Interior, Bureau of Reclamation.

Vaughan, S. (2011). 'Revolutionary democratic state-building: party, state and people in the EPRDF's Ethiopia'. Journal of Eastern African Studies 5, 619-640.

Vaughan, S. and Tronvoll, K. (2003). The Culture of Power in Contemporary Ethiopian Political Life. Stockholm: Swedish International Development Cooperation Agency.

Verhoeven, H. (2013). 'The politics of African energy development: Ethiopia's hydroagricultural state-building strategy and clashing paradigms of water security'. Philosophical Transactions of the Royal Society A: Mathematical, Physical and Engineering Sciences 371(2002).

Waldner, D. (1999). State Building and Late Development. Ithaca NY: Cornell University Press.

WAPCOS (1990). Preliminary Water Resource Development Master Plan for Ethiopia. Vol. II: Main Report. Addis Ababa: Water and Power Consultancy Services (WAPCOS).

Weis, T. (2015). 'Vanguard capitalism: party, state, and market in the EPRDF's Ethiopia'. PhD thesis. University of Oxford.

World Bank (1993). The World Bank's Role in the Electric Power Sector: Policies for Effective Institutional, Regulatory, and Financial Reform. Washington DC: World Bank Publications.

World Bank (1996). Ethiopia Energy Assessment. Washington DC: World Bank. 
World Bank (2006). Ethiopia: Managing Water Resources to Maximize Sustainable Growth. Washington DC: World Bank.

World Bank (2017). Moving Further on Civil Service Reforms in Ethiopia: Findings and Implications from a Civil Service Survey and Qualitative Analysis - Synthesis Report. Addis Ababa: World Bank.

Zarfl, C., Lumsdon, A.E., Berlekamp, J., Tydecks, L. and Tockner, K. (2015). 'A global boom in hydropower dam construction'. Aquatic Sciences 77, 161-170.

Zenawi, M. (2009). 'Statement by HE Meles Zenaoui, Prime Minister of the Federal Democratic Republic of Ethiopia on Behalf of the African Group, Copenhagen, Denmark, December 16, 2009'. Address to the United Nations Climate Change Conference, Copenhagen.

Zenawi, M. (2012). 'States and markets: neo-liberal limitations and the case for a developmental state'. In Noman, A., Botchwey, K., Stein, H. and Stiglitz, J.E. (eds), Good Growth and Governance in Africa: Rethinking Development Strategies (pp. 140-174). Oxford: Oxford University Press.

Zenawi, M. (2015). 'What does the Green Economy have to do with us (Africans)?' [available at http://www.unep.org/environmentalgovernance/PerspectivesonRIO20/HEMrMelesZe nawi/tabid/55724/Default.aspx]. Accessed: 17 April 2015. 


\section{Annex 1: Interviews cited}

\section{Government respondents}

EG2, former senior official in the energy sector, Addis Ababa, 3 September 2019; 13 February 2020.

EG6, senior official in the energy sector, Addis Ababa, 3 October 2019.

EG8, former senior official in the energy sector, Addis Ababa, 3 October 2019; 11 February 2020.

EG9, senior official in the energy sector, Addis Ababa, 23 July 2019; 17 September 2019.

EG10, senior official in the energy sector, Addis Ababa, 17 July 2019.

EG11, senior official in the energy sector, Addis Ababa, 21 February 2020.

EG12, former senior official in the energy sector, Addis Ababa, 14 February 2020.

EG13, former senior official in the energy sector, Addis Ababa, 19 February 2020.

EG14, senior official in the energy sector, Addis Ababa, 3 October 2019.

EG16, senior official in the energy sector, Addis Ababa, 30 September 2019.

EG30, politician with responsibilities for the energy sector, Addis Ababa, 15 August 2019.

EG37, senior official in the energy sector, Addis Ababa, 21 August 2019; 19 February 2020.

EG44, former minister, Addis Ababa, 1 November 2018.

EG45, former advisor to the prime minister, 1 October 2018.

EG46, former TPLF central committee member, Addis Ababa, 7 August 2019.

\section{Private sector respondents}

EP11, former consultant to the energy sector, by phone, 25 November 2019.

EP12, contractor in the energy sector, by skype, 20 November 2019, 16 February 2020.

EP13, contractor in the energy sector, by skype, 26 November 2019.

EP14, former consultant to the energy sector, by phone, 10 March 2020.

\section{Donor representatives}

ED1, representative of a bilateral donor, Addis Ababa, 3 June 2019.

ED4, representative of a bilateral donor, Addis Ababa, 18 February 2020.

ED9, representative of a bilateral donor, by skype, 18 October 2019.

ED10, representative of a bilateral donor, Addis Ababa, 6 June 2019.

ED16, representative of a multilateral_organisation, by skype, 5 June 2020. 